\title{
Toughening alumina with both nickel and zirconia inclusions
}

\author{
R.Z. Chen, Y.T. Chiu, W.H. Tuan* \\ Institute of Materials Science and Engineering, National Taiwan University, Taipei 106, Taiwan, ROC
}

Received 14 September 1999; received in revised form 8 March 2000; accepted 13 March 2000

\begin{abstract}
In the present study, the interactions between a transformation toughening mechanism and a plastic deformation toughening mechanism are explored by investigating the toughening behaviour of $\mathrm{Al}_{2} \mathrm{O}_{3} /\left(\mathrm{ZrO}_{2}+\mathrm{Ni}\right)$ composites. Both the phase transformation of $\mathrm{ZrO}_{2}$ inclusions and the plastic deformation of $\mathrm{Ni}$ inclusions can enhance the toughness of $\mathrm{Al}_{2} \mathrm{O}_{3}$. However, the presence of $\mathrm{Ni}$ inclusions increases the amount of tetragonal-monoclinic transformation, the toughness enhancement of $\mathrm{Al}_{2} \mathrm{O}_{3} /\left(\mathrm{ZrO}_{2}+\mathrm{Ni}\right)$ composites is therefore higher than the sum of the toughness enhancement of $\mathrm{Al}_{2} \mathrm{O}_{3} / \mathrm{ZrO}_{2}$ and of $\mathrm{Al}_{2} \mathrm{O}_{3} / \mathrm{Ni}$ composites. C) 2000 Elsevier Science Ltd. All rights reserved.
\end{abstract}

Keywords: $\mathrm{Al}_{2} \mathrm{O}_{3}$; Composite; Microsture-final; Ni; Toughness and toughening; $\mathrm{ZrO}_{2}$

\section{Introduction}

The applications of ceramics as structural components are often limited by their brittleness. A major research objective for ceramic communities has, therefore, been to improve the toughness of ceramics. The addition of second-phase inclusions that influence the propagation of cracks has been one much studied approach. Among the second phase inclusions studied, zirconia particles and silicon carbide whiskers have received great attention. ${ }^{1-3}$ With the addition of either zirconia particles, ${ }^{1}$ or zirconia agglomerates, ${ }^{2}$ or silicon carbide whiskers, ${ }^{3}$ not only the toughness of the ceramic matrix is enhanced but also the strength is frequently increased.

Previous studies mainly concentrated on the toughening behaviour of the composites containing only one toughening agent. ${ }^{1-3}$ However, the toughness enhancement of a ceramic matrix containing multiple toughening agents may be higher than the sum of the toughness increments. ${ }^{4,5}$ For example, the toughness increments of an $\mathrm{Al}_{2} \mathrm{O}_{3} / 15 \% \mathrm{ZrO}_{2}$ composite and an $\mathrm{Al}_{2} \mathrm{O}_{3} / 20 \% \mathrm{SiC}_{\mathrm{w}}$ composite are 1.5 and $3.8 \mathrm{MPa} \mathrm{m}^{0.5}$, respectively. ${ }^{4}$ However, the toughness increment for the $\mathrm{Al}_{2} \mathrm{O}_{3} /(15 \%$ $\mathrm{ZrO}_{2}+20 \% \mathrm{SiC}_{\mathrm{w}}$ ) composite is $8.8 \mathrm{MPa} \mathrm{m} \mathrm{m}^{0.5}$, which is higher than the sum of the toughness increments of the

* Corresponding author. Tel.: + 886-2-2365-9800; fax: +886-22363-4562.

E-mail address: tuan@ccms.ntu.edu.tw (W.H. Tuan). composites containing only $\mathrm{ZrO}_{2}$ and only $\mathrm{SiC}_{\mathrm{w}}$. Becher and Tiegs suggested that toughening mechanisms can interact with each other to produce a synergistic effect. ${ }^{5}$ However, the experimental data from other groups show contradictory results. For example, Jang et al. showed that the toughness increment of an $\mathrm{Al}_{2} \mathrm{O}_{3} /\left(15 \% \mathrm{ZrO}_{2}+\right.$ $20 \% \mathrm{SiC}_{\mathrm{w}}$ ) composite is $8.3 \mathrm{MPa} \mathrm{m}^{0.5}$, which is similar to the sum of the toughness increment of the $\mathrm{Al}_{2} \mathrm{O}_{3}$ $15 \% \mathrm{ZrO}_{2}\left(2.1 \mathrm{MPa} \mathrm{m}^{0.5}\right)$ and of the $\mathrm{Al}_{2} \mathrm{O}_{3} / 20 \% \mathrm{SiC}_{\mathrm{w}}$ (4.9 $\mathrm{MPa} \mathrm{m}{ }^{0.5}$ ) composites. ${ }^{6}$ Tuan and Chen showed that the toughness enhancement of an $\mathrm{Al}_{2} \mathrm{O}_{3} /\left(15 \% \mathrm{ZrO}_{2}+\right.$ $15 \% \mathrm{Ag}$ ) composite $\left(2.0 \mathrm{MPa} \mathrm{m}^{0.5}\right)$ is lower than the sum of the toughness enhancement of the $\mathrm{Al}_{2} \mathrm{O}_{3} / 15 \% \mathrm{Ag}(2.0$ $\left.\mathrm{MPa} \mathrm{m}^{0.5}\right)$ and of the $\mathrm{Al}_{2} \mathrm{O}_{3} / 15 \% \mathrm{ZrO}_{2}\left(0.7 \mathrm{MPa} \mathrm{m}^{0.5}\right)$ composites. $^{7}$

The interactions between different toughening mechanisms have received little attention, although different toughening mechanisms frequently co-exist in composites containing only one toughening agent. It may in part be because the contribution from each toughening mechanism is usually not known or is difficult to quantify. In the present study, two toughening agents with known toughening mechanisms are added to a ceramic matrix to investigate the interactions between the two. The present study may also elucidate the interactions between different toughening mechanisms which are provided by only one toughening agents. Once the interactions between different toughening mechanisms are understood, the factors which can produce a synergistic effect can then be explored and exploited. 
The toughness of ceramics can be improved by utilising the transformation ability of the zirconia particles. ${ }^{1,2}$ Recent studies also suggested that ceramics can be effectively toughened through the addition of nickel inclusions. ${ }^{8,9}$ The toughness enhancement is believed to be due to the plastic deformation of the ductile inclusions. In the present study, we have chosen zirconia particles and nickel particles as the toughening agents for an alumina matrix as the toughening mechanisms for the composites containing only zirconia or only nickel inclusions are well identified.

\section{Experimental}

Alumina (TM-DR, Taimei Chem. Co. Ltd., Tokyo, Japan) and nickel oxide (NiO, mean particle size $=16 \mu \mathrm{m}$, Johnson Matthey Co., USA) and/or zirconia $\left(\mathrm{ZrO}_{2}+3\right.$ mol\% $\mathrm{Y}_{2} \mathrm{O}_{3}$, Hanwha Ceramics Co., Australia) were ball milled together in ethyl alcohol for $24 \mathrm{~h}$. The grinding media used were zirconia balls. The slurry of the powder mixtures was dried with a rotary evaporator. The dried lumps were crushed and passed through a plastic sieve. Powder compacts with dimensions of $7 \times 6 \times 50 \mathrm{~mm}$ were formed by uniaxially pressing at $44 \mathrm{MPa}$. The green compacts containing $\mathrm{NiO}$ particles, such as $\mathrm{Al}_{2} \mathrm{O}_{3} / \mathrm{NiO}$ and $\mathrm{Al}_{2} \mathrm{O}_{3} /\left(\mathrm{ZrO}_{2}+\mathrm{NiO}\right)$ compacts, were sintered within a covered graphite crucible. The graphite could generate a reducing atmosphere, $\mathrm{CO}$, during sintering at $1600^{\circ} \mathrm{C}$. The nickel oxide could then be reduced to result in nickel inclusions after sintering. The heating rate and cooling rate were $5^{\circ} \mathrm{C} / \mathrm{min}$. The dwell time at the sintering temperature was $1 \mathrm{~h}$. The $\mathrm{Al}_{2} \mathrm{O}_{3}$ and $\mathrm{Al}_{2} \mathrm{O}_{3} / \mathrm{ZrO}_{2}$ green compacts were, for comparison reason, also sintered in a covered graphite crucible with the same firing schedule. Some discs with $2.54 \mathrm{~cm}$ diameter were also prepared for the measurement of elastic modulus, which was determined with an ultrasonic technique.

The sintered specimens were machined longitudinally with a 325 grit resin-bonded diamond wheel at a cutting depth of $5 \mu \mathrm{m} /$ pass. The final dimensions of the specimens were $3 \times 4 \times 36 \mathrm{~mm}$. The strength of the specimens was determined by 4-point bending at ambient, room-temperature conditions. The upper and lower spans were 10 and $30 \mathrm{~mm}$, respectively. The rate of loading was 0.5 $\mathrm{mm} / \mathrm{min}$. The fracture toughness was determined by the single-edge-notched-beam (SENB) technique. The notch was generated by cutting with a diamond saw. The width of the notch was around $0.3 \mathrm{~mm}$.

Phase identification of sintered and machined specimens was performed by X-ray diffractometry with $\mathrm{Cu} K_{\alpha}$ radiation. The relative phase content for the dispersed zirconia was estimated by using the method proposed by Evans et al. ${ }^{10}$ The final density of the specimens was determined by the Archimedes method. To be shown later, there were no interactions between each phase in the sintered composites. The relative density of the sintered composites was estimated by using the theoretical density of $3.98 \mathrm{~g} / \mathrm{cm}^{3}$ for $\mathrm{Al}_{2} \mathrm{O}_{3}$, and $6.05 \mathrm{~g} / \mathrm{cm}^{3}$ for $\mathrm{ZrO}_{2}$ and $8.90 \mathrm{~g} / \mathrm{cm}^{3}$ for Ni. Polished surfaces were prepared by grinding and polishing with diamond paste to $6 \mu \mathrm{m}$ and with silica suspension to $0.05 \mu \mathrm{m}$. As Ni could vaporize during sintering, the volume fraction of $\mathrm{Ni}$ in the specimens after sintering was determined with an image analysis technique. The polished specimens were then thermally etched at $1550^{\circ} \mathrm{C}$ in a high-purity nitrogen to reveal the grain boundaries of matrix grains. Microstructural characterization used scanning electron microscopy

Table 1

The relative density, nickel content after sintering, the size of $\mathrm{Al}_{2} \mathrm{O}_{3}$ grains and of $\mathrm{ZrO}_{2}$ inclusions, and the elastic modulus of the sintered $\mathrm{Al}_{2} \mathrm{O}_{3}$, $\mathrm{Al}_{2} \mathrm{O}_{3} / \mathrm{ZrO}_{2}, \mathrm{Al}_{2} \mathrm{O}_{3} / \mathrm{Ni}$ and $\mathrm{Al}_{2} \mathrm{O}_{3} /\left(\mathrm{ZrO}_{2}+\mathrm{Ni}\right)$ specimens

\begin{tabular}{|c|c|c|c|c|c|}
\hline Systems & $\begin{array}{l}\text { Relative } \\
\text { density }(\%)\end{array}$ & $\begin{array}{l}\text { Nickel content } \\
\text { after sintering }(\%)\end{array}$ & $\begin{array}{l}\text { Size of alumina } \\
\text { grains }(\mu \mathrm{m})\end{array}$ & $\begin{array}{l}\text { Size of zirconia } \\
\text { inclusions }(\mu \mathrm{m})\end{array}$ & $\begin{array}{l}\text { Elastic } \\
\text { modulus (GPa) }\end{array}$ \\
\hline $\mathrm{Al}_{2} \mathrm{O}_{3}$ & 99.7 & - & 10.20 & - & 396 \\
\hline+5 vol. $\% \mathrm{ZrO}_{2}$ & 99.5 & - & 2.12 & 0.27 & 388 \\
\hline+7.5 vol. $\% \mathrm{ZrO}_{2}$ & 98.2 & - & 2.05 & 0.34 & 381 \\
\hline+10 vol. $\% \mathrm{ZrO}_{2}$ & 99.4 & - & 1.99 & 0.32 & 381 \\
\hline+12.5 vol. $\% \mathrm{ZrO}_{2}$ & 99.4 & - & 1.72 & 0.34 & 375 \\
\hline+15 vol. $\% \mathrm{ZrO}_{2}$ & 97.5 & - & 1.47 & 0.36 & 360 \\
\hline+5 vol. $\% \mathrm{Ni}$ & 99.6 & 4.7 & 6.64 & - & 351 \\
\hline+7.5 vol. $\% \mathrm{Ni}$ & 98.7 & 6.7 & 4.59 & - & 320 \\
\hline+10 vol. $\% \mathrm{Ni}$ & 99.1 & 8.7 & 4.39 & - & 285 \\
\hline+12.5 vol. $\% \mathrm{Ni}$ & 97.6 & 10.8 & 4.33 & - & 309 \\
\hline+15 vol. $\% \mathrm{Ni}$ & 98.1 & 12.9 & 3.80 & - & 274 \\
\hline+5 vol. $\% \mathrm{ZrO}_{2}+5$ vol. $\% \mathrm{Ni}$ & 99.7 & 4.7 & 1.86 & 0.35 & 362 \\
\hline+7.5 vol. $\% \mathrm{ZrO}_{2}+7.5$ vol. $\% \mathrm{Ni}$ & 99.2 & 6.7 & 1.76 & 0.29 & 357 \\
\hline+10 vol. $\% \mathrm{ZrO}_{2}+10$ vol. $\% \mathrm{Ni}$ & 98.6 & 8.8 & 1.56 & 0.32 & 337 \\
\hline+12.5 vol. $\% \mathrm{ZrO}_{2}+12.5$ vol. $\% \mathrm{Ni}$ & 98.8 & 11.0 & 1.50 & 0.33 & 327 \\
\hline+15 vol. $\% \mathrm{ZrO}_{2}+15$ vol. $\% \mathrm{Ni}$ & 95.5 & 13.2 & 1.40 & 0.43 & 297 \\
\hline
\end{tabular}


(SEM). The size of the matrix grains and of zirconia inclusions was determined by using the line intercept technique.

\section{Results and discussion}

\subsection{Phase analysis and microstructural characterisation}

The phases presented on the surface of the composites after sintering are $\alpha-\mathrm{Al}_{2} \mathrm{O}_{3}, t-\mathrm{ZrO}_{2}$ and $\mathrm{Ni}$. No nickel oxide is detected by XRD analysis either on the surface or on the cross section of the composites. The relative density, the volume fraction of $\mathrm{Ni}$, the size of matrix grains and of zirconia inclusions, and elastic modulus of the sintered $\mathrm{Al}_{2} \mathrm{O}_{3}, \mathrm{Al}_{2} \mathrm{O}_{3} / \mathrm{ZrO}_{2}, \mathrm{Al}_{2} \mathrm{O}_{3} / \mathrm{Ni}, \mathrm{Al}_{2} \mathrm{O}_{3} /\left(\mathrm{ZrO}_{2}+\mathrm{Ni}\right)$ composites are shown in Table 1. Except the composite containing $15 \mathrm{vol} . \% \mathrm{ZrO}_{2}$ and $15 \mathrm{vol} . \% \mathrm{Ni}$, the density of the composites is higher than $97 \%$. The nickel can vaporize during sintering at $1600^{\circ} \mathrm{C}$, the volume fraction of $\mathrm{Ni}$ is thus slightly lower than the amount added in the starting materials.

The polished section of the composites containing 15 vol. $\% \mathrm{ZrO}_{2}$ or 15 vol. $\% \mathrm{Ni}$ and $\left(15\right.$ vol. $\% \mathrm{ZrO}_{2}+15$ vol. \% Ni) are shown in Fig. 1(a), (b) and (c), respectively. The $\mathrm{ZrO}_{2}$ particles and $\mathrm{Ni}$ inclusions are distributed uniformly in the $\mathrm{Al}_{2} \mathrm{O}_{3}$ matrix. The size of $\mathrm{ZrO}_{2}$ particles is much smaller than that of $\mathrm{Ni}$ inclusions. The $\mathrm{ZrO}_{2}$ and $\mathrm{Ni}$ inclusions in the composites containing both $\mathrm{ZrO}_{2}$ and $\mathrm{Ni}$ inclusions can thus be distinguished from each other from the size difference. The microstructures of the thermally etched surfaces are shown in Fig. 2(a)-(d). Most the $\mathrm{Ni}$ and $\mathrm{ZrO}_{2}$ inclusions are located at the grain boundaries of alumina matrix. Pores are also frequently situated at the grain boundaries of matrix grains. The size of $\mathrm{Al}_{2} \mathrm{O}_{3}$ matrix grains is shown as a function of total inclusion content in Fig. 3. The presence of zirconia particles slows down the movement of the grain boundaries of alumina, ${ }^{11}$ such that the grain size of the alumina matrix is decreased. Likewise, the existence of nickel inclusions can induce segregation of nickel ions to the grain boundaries of alumina, also limiting the grain growth of alumina. ${ }^{8}$ The size of the matrix grains in the composites thus decreases with increasing inclusion content.

\subsection{Mechanical properties}

The flexural strength of the composites is shown as a function of total inclusion content in Fig. 4. The points in the figure show the average values of 4-6 specimens. The standard deviation is also shown in the figure. The strength of $\mathrm{Al}_{2} \mathrm{O}_{3}$ is increased by adding $\mathrm{ZrO}_{2}$, or $\mathrm{Ni}$ or both $\mathrm{ZrO}_{2}$ and $\mathrm{Ni}$ inclusions. The strength of the composites is shown as a function of the size of $\mathrm{Al}_{2} \mathrm{O}_{3}$ matrix grains in Fig. 5. The strength of the composites, $\sigma$, shows the following relationship with the grain size of $\mathrm{Al}_{2} \mathrm{O}_{3}, G$ :
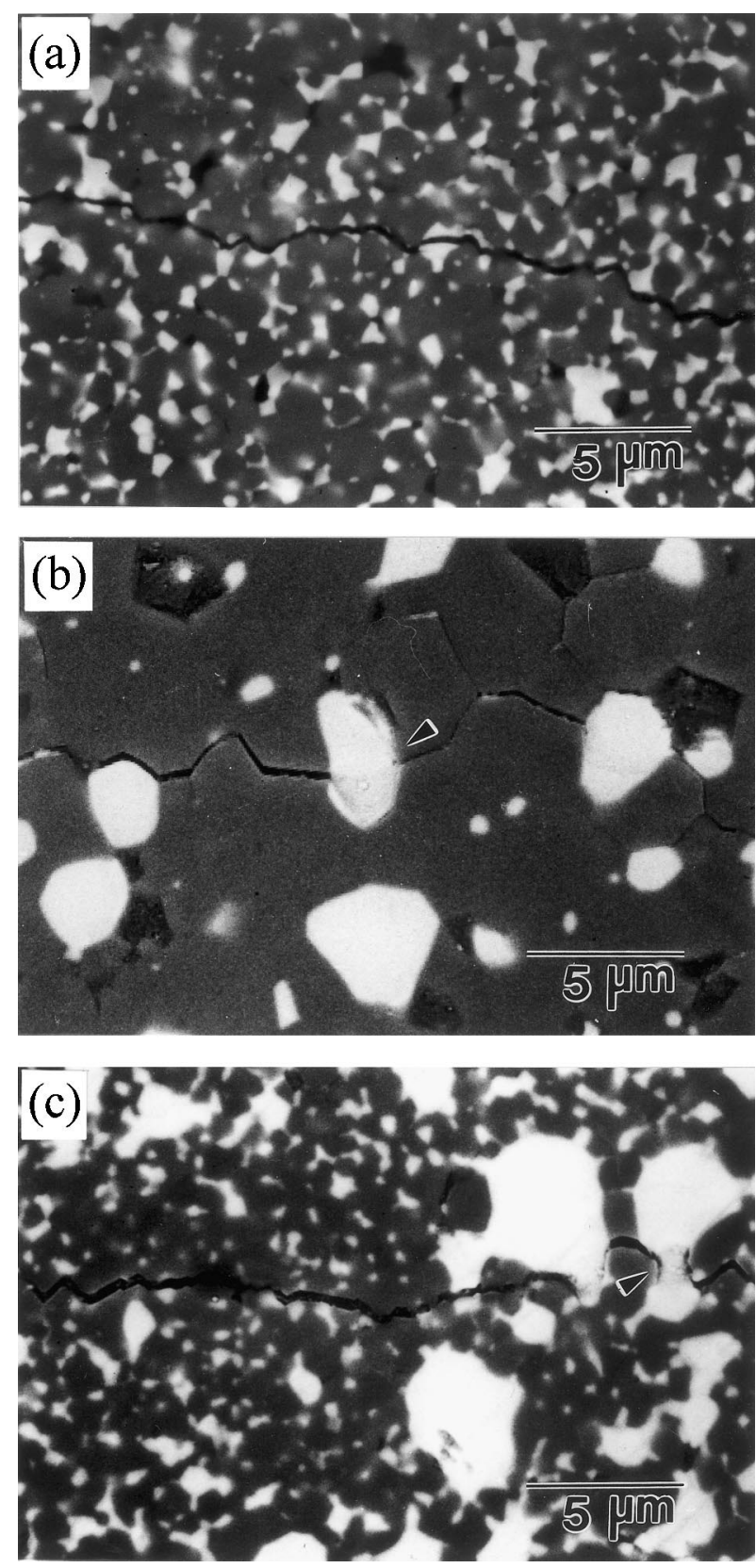

Fig. 1. Polished surfaces of the composites containing (a) 15 vol. \% $\mathrm{ZrO}_{2}$, (b) 15 vol. $\% \mathrm{Ni}$ and (c) 15 vol. $\% \mathrm{ZrO}_{2}+15$ vol. $\%$ Ni inclusions. The crack was introduced by indentation. Some nickel inclusions which bridge crack surfaces in (b) and (c) are indicated with arrows.

$\sigma=\sigma_{\mathrm{o}} G^{-1 / b}$

where $\sigma_{\mathrm{o}}$ and $b$ are constants. Such a relationship is also found for monolithic alumina. ${ }^{12}$ This suggests that the size of matrix grains dominates the strength of the composites. Furthermore, by taking the strength in the range of 350-600 MPa for the composites investigated in the present study, and the toughness in the range of 4-9 MPa $\mathrm{m}^{0.5}$ (Fig. 6), the size of the flaws in the composites is estimated in the range of tens of micrometers. The size of flaw is much larger than that of inclusions, it indicates 

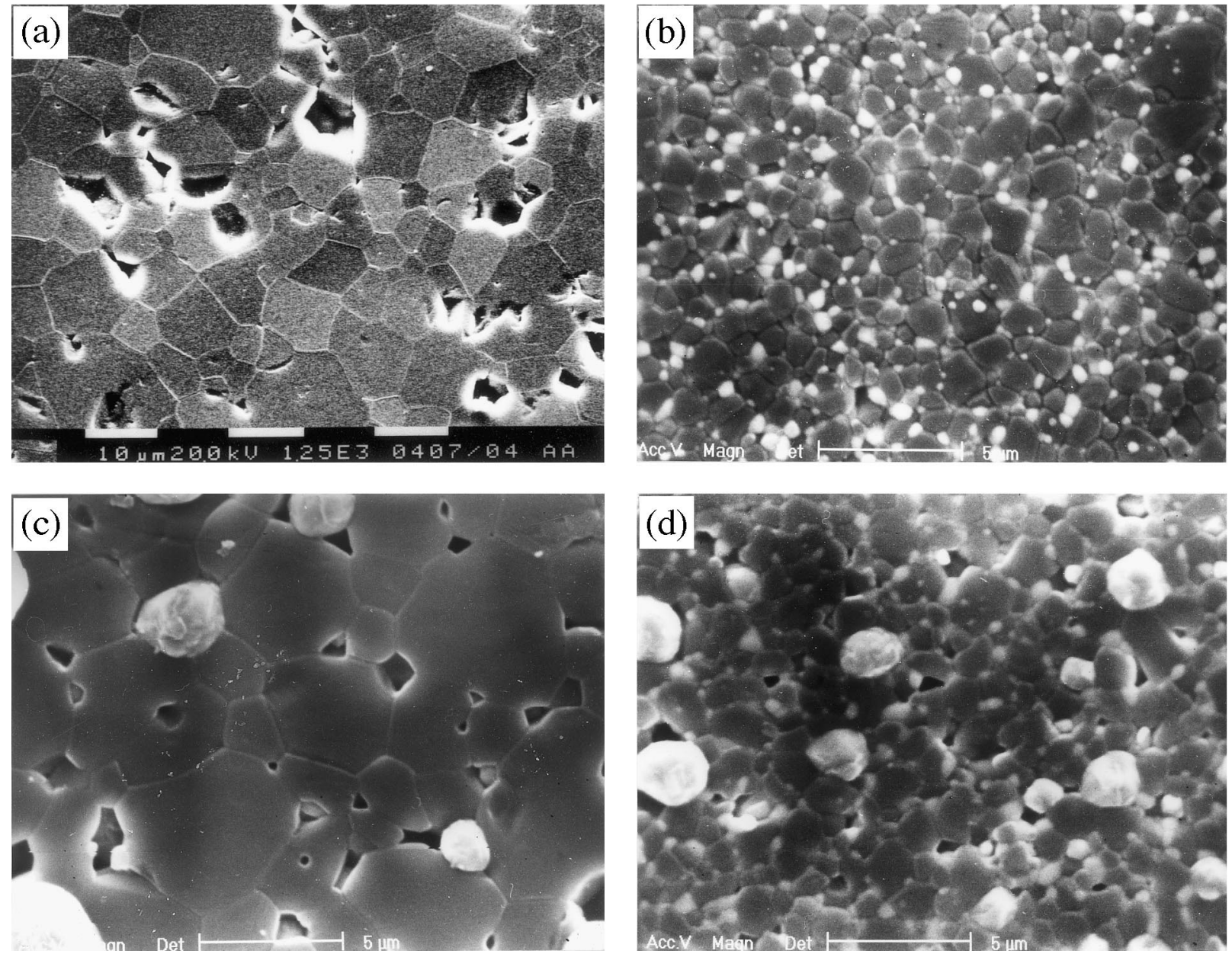

Fig. 2. Microstructures of (a) $\mathrm{Al}_{2} \mathrm{O}_{3}$ and the composites containing (b) 15 vol. $\% \mathrm{ZrO}_{2}$, (c) 15 vol. $\%$ Ni and (d) 15 vol. $\% \mathrm{ZrO}+15$ vol. $\%$ Ni inclusions.

that the flaws are located in the matrix. The strength of the composites is, therefore, higher as a consequence of their refined microstructure.

The fracture toughness of the composites is shown as a function of total inclusion content in Fig. 6. Each datum point in the figure shows the average value of 4 specimens. Except for the composites containing 15\% $\mathrm{ZrO}_{2}$ (with or without $\mathrm{Ni}$ ), the toughness of the composites increases with increasing inclusion content.

Fig. 7 shows the amount of monoclinic phase on the fracture surfaces of the $\mathrm{Al}_{2} \mathrm{O}_{3} / \mathrm{ZrO}_{2}$ and $\mathrm{Al}_{2} \mathrm{O}_{3} /\left(\mathrm{ZrO}_{2}+\mathrm{Ni}\right)$ composites after strength measurement. From XRD analysis, the $\mathrm{ZrO}_{2}$ particles were $100 \%$ tetragonal phase in the composites after sintering. Less than $10 \%$ tetragonal phase is transformed to monoclinic phase in the $\mathrm{Al}_{2} \mathrm{O}_{3}$ / $\mathrm{ZrO}_{2}$ composites after fracture. The $\mathrm{ZrO}_{2}$ particles are small (Table 1) and distributed uniformly in the $\mathrm{Al}_{2} \mathrm{O}_{3}$ matrix such that the constraint applied by the $\mathrm{Al}_{2} \mathrm{O}_{3}$ matrix is large enough to prohibit most from transforming. ${ }^{13}$ The toughness of $\mathrm{Al}_{2} \mathrm{O}_{3} / \mathrm{ZrO}_{2}$ composites is thus slightly higher than that of $\mathrm{Al}_{2} \mathrm{O}_{3}$ as a consequence of the limited amount of phase transformation, Fig. 6. The amount of

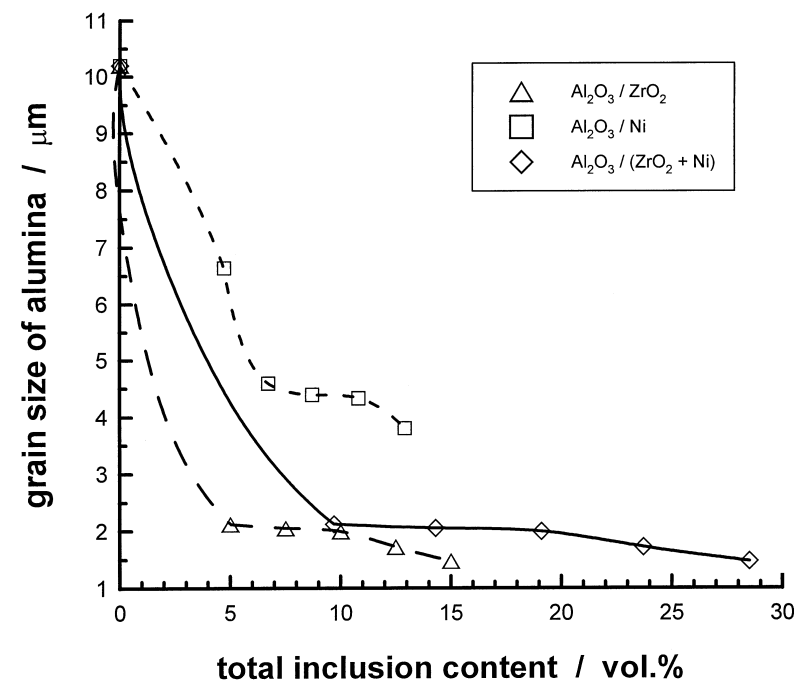

Fig. 3. The grain size of the alumina matrix as a function of total inclusion content.

monoclinic phase is increased as $\mathrm{Ni}$ inclusions are added into $\mathrm{Al}_{2} \mathrm{O}_{3} / \mathrm{ZrO}_{2}$ matrix. The elastic modulus of $\mathrm{Al}_{2} \mathrm{O}_{3} /$ $\mathrm{Ni}$ composites is lower than that of $\mathrm{Al}_{2} \mathrm{O}_{3}$ (Table 1). The constraint applied on the $\mathrm{ZrO}_{2}$ particles is reduced 


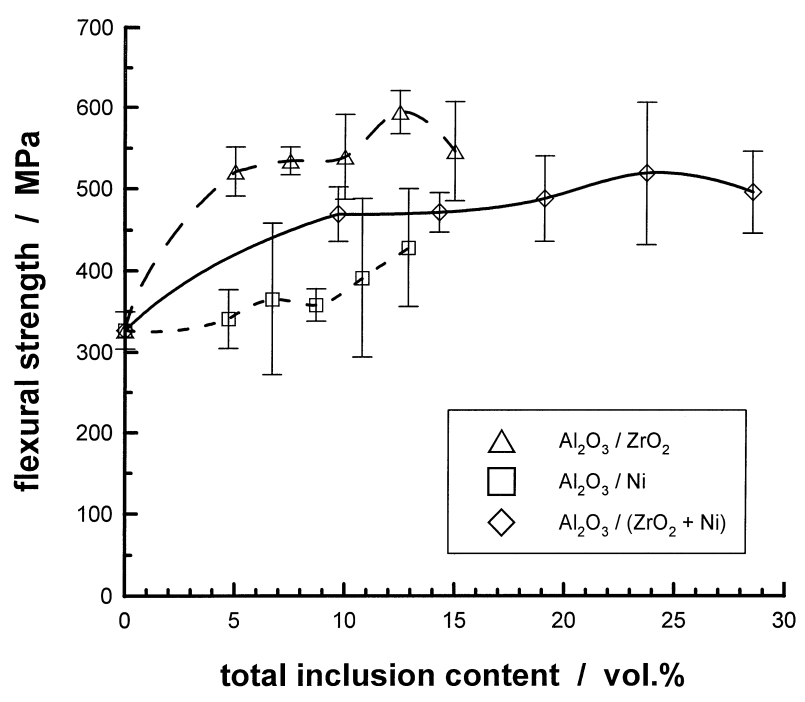

Fig. 4. The flexural strength of the composites as a function of total inclusion content.

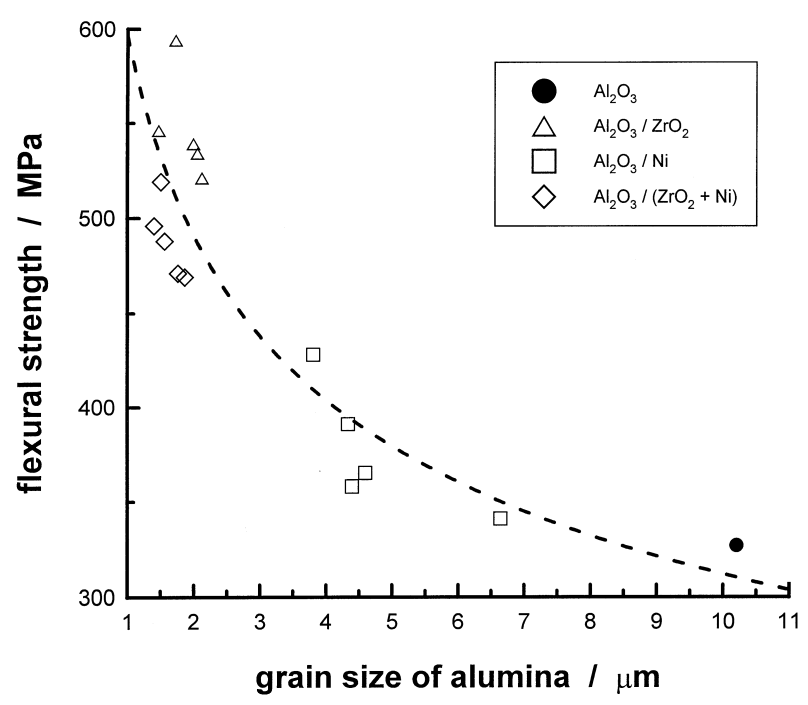

Fig. 5. The flexural strength of the composites as a function of matrix grain size.

due to the presence of $\mathrm{Ni}$ particles in the $\mathrm{Al}_{2} \mathrm{O}_{3}$ matrix such that more tetragonal $\mathrm{ZrO}_{2}$ particles transform to monoclinic phase during fracture.

Fig. 8 shows the fracture surface of an $\mathrm{Al}_{2} \mathrm{O}_{3} / \mathrm{Ni}$ composite. Stretched nickel particles can be observed above the plane of the fracture surface. Furthermore, the crack surfaces are bridged by the some stretching inclusions, Fig. 1. It indicates that some of the Ni particles are plastically deformed during the fracture process. The toughness of $\mathrm{Al}_{2} \mathrm{O}_{3}$ is therefore enhanced by the plastic deformation of nickel inclusions.

Fig. 9 shows the toughness increase of the $\mathrm{Al}_{2} \mathrm{O}_{3} /$ $\left(\mathrm{ZrO}_{2}+\mathrm{Ni}\right)$ composites as a function of total inclusion content. The sum of the toughness increments of the composites containing only $\mathrm{ZrO}_{2}$ inclusions and only $\mathrm{Ni}$ inclusions is also shown on the figure for comparison purposes.

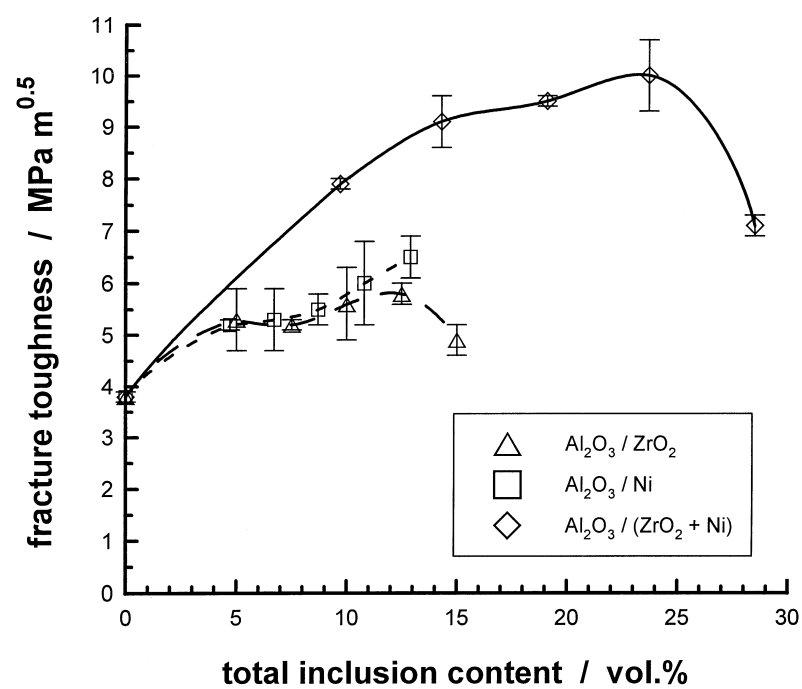

Fig. 6. The fracture toughness of the composites as a function of total inclusion content.

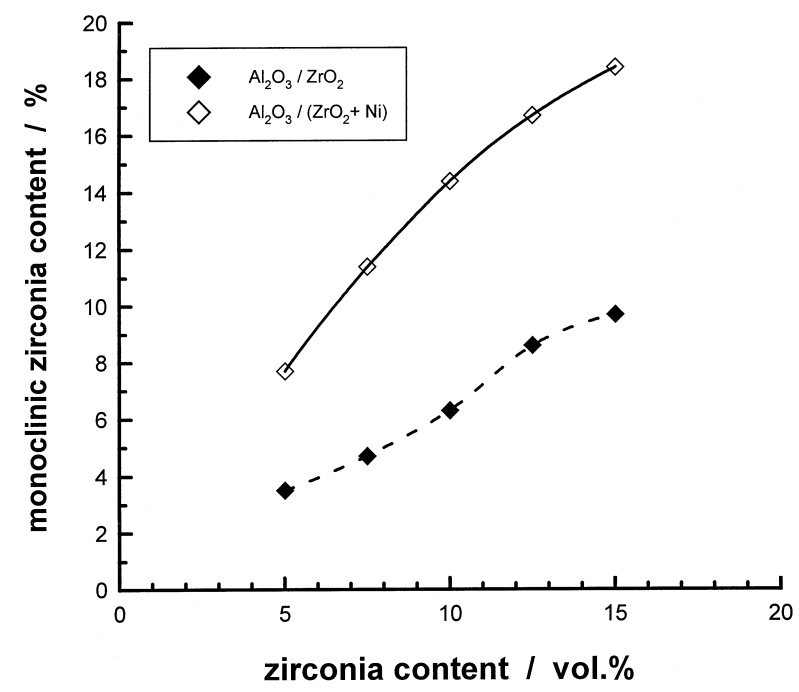

Fig. 7. The amount of monoclinic phase of $\mathrm{ZrO}_{2}$ on the fracture surface as a function of zirconia content. In the $\mathrm{Al}_{2} \mathrm{O}_{3} /\left(\mathrm{ZrO}_{2}+\mathrm{Ni}\right)$ composites, the volume fraction of $\mathrm{ZrO}_{2}$ is nearly the same as that of $\mathrm{Ni}$, the total inclusion content in the composites is thus almost doubled the value indicated in the $\mathrm{x}$-axis.

Except the composite containing $15 \% \mathrm{ZrO}_{2}+15 \% \mathrm{Ni}$, the toughness enhancement of the composites containing two toughening agents is higher than the addition of the toughness enhancement of the composites containing single toughening agent. It is likely that the phase transformation of $\mathrm{ZrO}_{2}$ particles took place independently of the plastic deformation of $\mathrm{Ni}$ particles; namely, the $\mathrm{ZrO}_{2}$ particles and $\mathrm{Ni}$ particles are acted independently on the crack. The contribution from the toughness increase from the $\mathrm{ZrO}_{2}$ and $\mathrm{Ni}$ particles can thus be added together. However, the presence of Ni inclusions increases the transformation ability of $\mathrm{ZrO}_{2}$, Fig. 7. The toughness increase of the composites containing both $\mathrm{ZrO}_{2}$ and $\mathrm{Ni}$ inclusions is therefore higher than the sum 


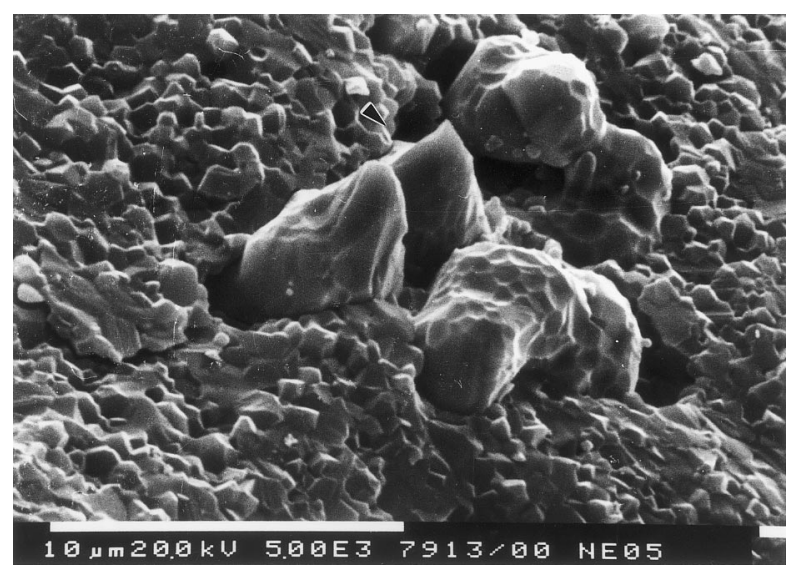

Fig. 8. The fracture surface of a composite containing 5 vol. $\% \mathrm{Ni}$ inclusions. A plastically deformed $\mathrm{Ni}$ inclusion is indicated with an arrow.

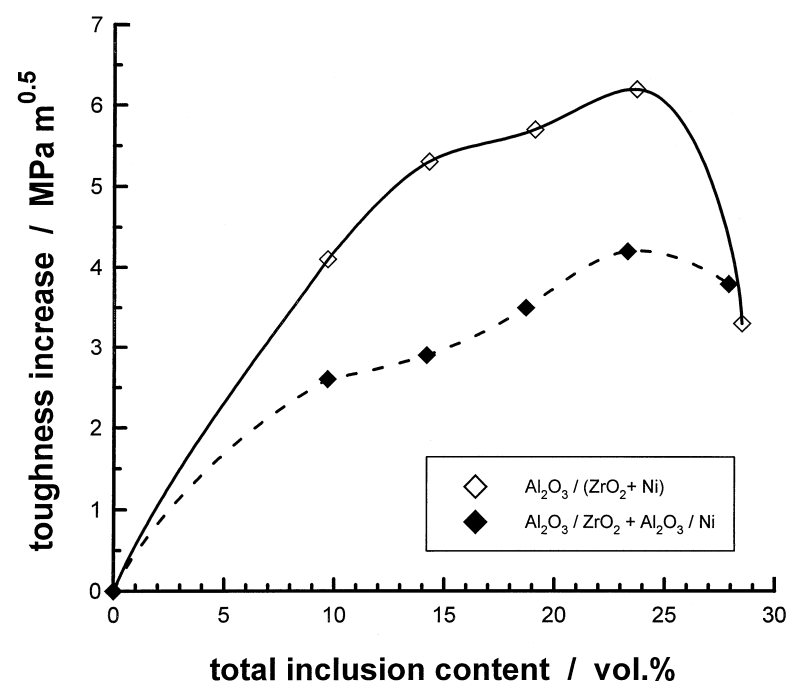

Fig. 9. The toughness increase of the $\mathrm{Al}_{2} \mathrm{O}_{3} /\left(\mathrm{ZrO}_{2}+\mathrm{Ni}\right)$ composites as a function of total inclusion content. The sum of the toughness increase of the $\mathrm{Al}_{2} \mathrm{O}_{3} / \mathrm{ZrO}_{2}$ composites and of the $\mathrm{Al}_{2} \mathrm{O}_{3} / \mathrm{Ni}$ composites is also shown for comparison.

of the toughness increase of the composites containing only $\mathrm{ZrO}_{2}$ and only $\mathrm{Ni}$ inclusions. The density of the $\mathrm{Al}_{2} \mathrm{O}_{3} /$ $\left(15 \% \mathrm{ZrO}_{2}+15 \% \mathrm{Ni}\right)$ composite is the lowest among all the composites investigated (Table 1). The toughness increase of the composite is thus relatively low as a consequence of its low density.

Previous study on the $\mathrm{Al}_{2} \mathrm{O}_{3} /\left(\mathrm{ZrO}_{2}+\mathrm{Ag}\right)$ composites showed that the toughness increment of the $\mathrm{Al}_{2} \mathrm{O}_{3} /$ $\left(\mathrm{ZrO}_{2}+\mathrm{Ag}\right)$ composites is lower than the sum of the toughness increment of the $\mathrm{Al}_{2} \mathrm{O}_{3} / \mathrm{ZrO}_{2}$ and $\mathrm{Al}_{2} \mathrm{O}_{3} / \mathrm{Ag}$ composites. ${ }^{7}$ In the $\mathrm{Al}_{2} \mathrm{O}_{3} /\left(\mathrm{ZrO}_{2}+\mathrm{Ag}\right)$ composites, $\mathrm{ZrO}_{2}$ agglomerates were used instead of $\mathrm{ZrO}_{2}$ particles. The $\mathrm{Ag}$ inclusions were associated with the $\mathrm{ZrO}_{2}$ agglomerates in the $\mathrm{Al}_{2} \mathrm{O}_{3} /\left(\mathrm{ZrO}_{2}+\mathrm{Ag}\right)$ composites after sintering. The transformation-induced stress is thus absorbed by the surrounding $\mathrm{Ag}$ inclusions, the toughness enhancement of the $\mathrm{Al}_{2} \mathrm{O}_{3} /\left(\mathrm{ZrO}_{2}+\mathrm{Ag}\right)$ composites is therefore low. The $\mathrm{ZrO}_{2}$ and $\mathrm{Ni}$ inclusions are separated from each other in the $\mathrm{Al}_{2} \mathrm{O}_{3} /\left(\mathrm{ZrO}_{2}+\mathrm{Ni}\right)$ composites prepared in the present study. The transformation stress induced by the $\mathrm{ZrO}_{2}$ particles can act independently on the crack surfaces. Therefore, the toughness increase of the $\mathrm{Al}_{2} \mathrm{O}_{3} /\left(\mathrm{ZrO}_{2}+\mathrm{Ni}\right)$ composites is higher.

\section{Conclusions}

The strength and toughness of $\mathrm{Al}_{2} \mathrm{O}_{3}$ can be enhanced by adding both $\mathrm{ZrO}_{2}$ and $\mathrm{Ni}$ inclusions. The strengthening effect for the $\mathrm{Al}_{2} \mathrm{O}_{3} /\left(\mathrm{ZrO}_{2}+\mathrm{Ni}\right)$ composites is attributed to refined microstructures. The presence of Ni particles increases the transformation ability of $\mathrm{ZrO}_{2}$ inclusions due to the low elastic modulus of $\mathrm{Ni}$, such that the toughness increase of $\mathrm{Al}_{2} \mathrm{O}_{3} /\left(\mathrm{ZrO}_{2}+\mathrm{Ni}\right)$ composites is higher than the sum of the toughness increases of the composites containing only $\mathrm{ZrO}_{2}$ and only $\mathrm{Ni}$ inclusions.

\section{References}

1. Claussen, N., Microstructural design of zirconia-toughened ceramics (ZTC). In Advances in Ceramics, ed. N. Claussen, M. Rühle and A. M. Heuer. Am Ceram Soc, Columbus, OH, 1984, pp. 325-351.

2. Wang, J. and Stevens, R., Toughening mechanisms in duplex alumina-zirconia ceramics. J. Mater. Sci., 1988, 23, 804-808.

3. Wei, G. C. and Becher, P. F., Development of SiC-whisker-reinforced ceramics. Am. Ceram. Soc. Bull., 1985, 64, 298-304.

4. Claussen, N. and Petzow, G., Whisker-reinforced oxide ceramics. J. de Phys., Colloque C1, 1986, 47 (suppl. 2), 693-702.

5. Becher, P. F. and Tiegs, T. N., Toughening behavior involving multiple mechanisms: whisker reinforcement and zirconia toughening. J. Am. Ceram. Soc., 1987, 70, 651-654.

6. Jang, H. M., Moon, J. H. and Jang, C. W., Homogeneous fabrication of $\mathrm{Al}_{2} \mathrm{O}_{3}-\mathrm{ZrO}_{2}-\mathrm{SiC}$ whisker composite by surface-induced coating. J. Am. Ceram. Soc., 1992, 75, 3369-3376.

7. Tuan, W. H. and Chen, W. R., Mechanical properties of alumina-zirconia-silver composites. J. Am. Ceram. Soc., 1995, 78, 465-469.

8. Tuan, W. H. and Brook, R. J., The toughening of alumina with nickel inclusions. J. Eur. Ceram. Soc., 1990, 6, 31-37.

9. Sun, X. and Yeomans, J. A., Microstructure and fracture toughness of nickel particle toughened alumina matrix composites. $J$. Mater. Sci., 1996, 31, 875-880.

10. Evans, P. A., Stevens, R. and Binner, J. P., Quantitative X-ray diffraction analysis of polymorphic mixes of pure zirconia. Brit. Ceram. Trans. J., 1984, 84, 39-43.

11. Lange, F. F. and Hirlinger, M. M., Hindrance of grain growth in $\mathrm{Al}_{2} \mathrm{O}_{3}$ by $\mathrm{ZrO}_{2}$ inclusions. J. Am. Ceram. Soc., 1984, 67, 164-168.

12. Spriggs, R. M. and Vasilos, T., Effect of grain size on transverse bend strength of alumina and magnesia. J. Am. Ceram. Soc., 1963, 46, 224-228.

13. Garvie, R. C., Critical size effects in alumina-zirconia alloys. In Advances in Ceramics, ed N. Claussen, M. Rühle, and A. H. Heuer. Am Ceram Soc, Columbus, OH, 1988, vol. 24, pp. 55-69. 